PIOTR KUŁYK

MARIOLA MICHAŁOWSKA

\title{
Consumer behaviour on the e-commerce market in the light of empirical research in Lubuskie voivodeship
}

Prof. Eng. Piotr Kułyk University of Zielona Góra,

Faculty of Economics and Management

Mariola Michałowska, Ph.D. Eng. University of Zielona Góra,

Faculty of Economics and Management

\section{Introduction}

Changes taking effect in the market, particularly through the Internet, on the one hand, are not without influence on the course of management process of those doing business, and on the other hand, on consumer behavior. In the twenty-first century, in the era of information society the presence of a company on the Internet becomes particularly significant as well as discerning the opportunities of the use of the Internet in the company's functioning (Michałowska, Kotylak, Danielak 2015, p. 68).

E-commerce in Poland is one of the fastest growing sectors of the Polish economy. This situation indicates a change in consumer behavior, and it is necessary that appropriate measures are taken by operators. Building trust in e-commerce needs taking appropriate steps to identify the factors influencing the growth of customer confidence. It is a long process and a lot more difficult than in traditional trading. An important element of this process is the proper recognition of customers activity and their expectations in terms of service for e-commerce market. 
The main aim of this article was to identify the behavior of consumers in the e-commerce market in Poland, according to the model of e-customer as adopted by A. Meier and H. Stormer (2009, p. 73).

\section{The development of e-commerce market}

The importance of e-commerce, both in Poland and other European Union countries in the last dozen years, has been subject to dynamic changes. The main factor in the dynamic growth of the Internet economy is consumer spending on the Internet, driven largely by the growing popularity of the Internet (Cimochowski, Hutten-Czapski, Rał, Sass 2011, p. 8). According to the statistics from the research company PMR the total value of e-commerce market in 2015 amounted to PLN 31.8 billion (Handel Internetowy w Polsce...2015) and was higher by PLN 4.3 billion from the value of sales in the previous year. The value of e-commerce market in Poland in the years 2001-2015 is shown in figure 1. As is clear from the data given in figure 1 from year to year the share of transactions through the Internet increases. Polish consumers spent PLN 31.8 billion on online shopping in 2015, which represents an increase over the previous year by approx. $16 \%$. It should also be noted how growth rate of e-commerce market

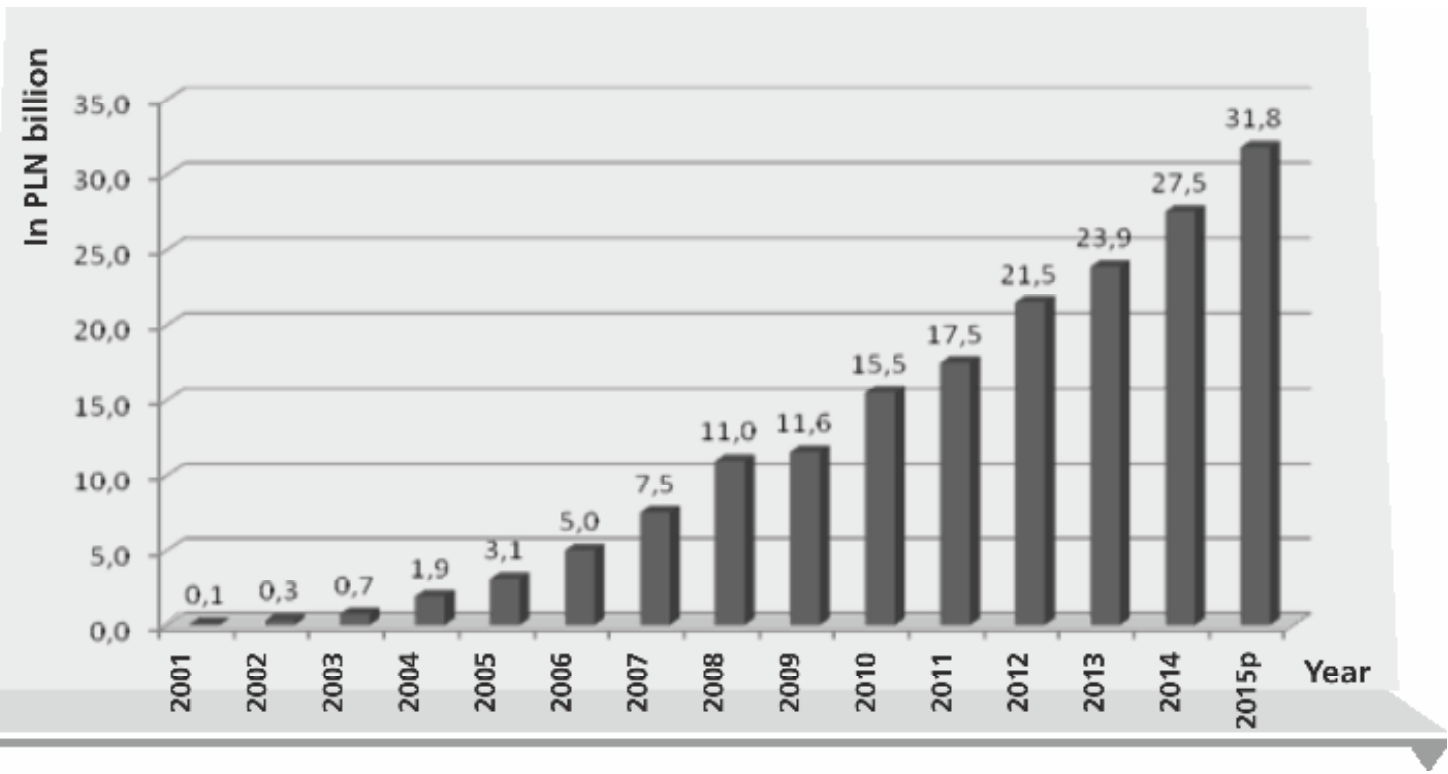

Figure 1. The value of e-commerce market in Poland in the years 2001-2015

Source: Garapich 2012, s. 5; A wave of Digital change... 2013, p. 46; Handel Internetowy w Polsce 2015 (p-prognosis)

Consumer behaviour on the e-commerce market in the light of empirical research in Lubuskie voivodeship 
in Poland presents itself in 2015 compared with 2001. In 2015 compared to 2001, there was a threefold increase in the market value of e-commerce. This raises the question of an attempt to define e-commerce.

B. Gregor and M. Stawiszyński (2002, p. 79) define e-commerce (e-commerce) as a process of buying and selling products and services, and thus make commercial transactions by electronic means, conducted through the Internet. According to the authors, the development of e-commerce can be divided into several main stages (Gregor, Stawiszyński 2002, p. 80):

1. Stage "before the Internet" e-commerce, where you can distinguish the initial phase/,traditional" e-commerce, which began the transmission of electronic documents through a VAN network (Eng. Value Added Network) and EDI (Eng. Electronic Data Interchange).

2. "Online” e-commerce stage, which included successive phases:

- the immature phase of e-commerce - presentation of a catalog offer,

- the phase of interactive links and the construction of a market society,

- the phase of the common market.

Table 1. Reduction of electronic commerce and how to overcome them

\begin{tabular}{|c|c|}
\hline Barriers to e-commerce & The way to overcome barriers \\
\hline $\begin{array}{l}\text { The customer does not see } \\
\text { the virtual seller }\end{array}$ & $\begin{array}{l}\text { By placing on the website a gallery of space sales and also } \\
\text { photographs the seller has significant impact on the perception } \\
\text { of e-business by potential customers. If you maintain a stationary } \\
\text { store you should enter the address of the store, as well as show the } \\
\text { pictures of the shop during customer service. }\end{array}$ \\
\hline $\begin{array}{l}\text { The customer knows little } \\
\text { about the seller }\end{array}$ & $\begin{array}{l}\text { On the website essential information should be included on the } \\
\text { conduct of business no matter whether the conducted online shop } \\
\text { sells at auction or services it should get rid of anonymity. }\end{array}$ \\
\hline $\begin{array}{l}\text { The customer does not know } \\
\text { the status of the company }\end{array}$ & $\begin{array}{l}\text { Giving the full name of the company its legal status, Tax } \\
\text { Identification Number and National Business Registry Number, } \\
\text { address and other registration data increases the company's } \\
\text { credibility in the eyes of their customers. }\end{array}$ \\
\hline $\begin{array}{l}\text { The customer does not know } \\
\text { the company's achievements }\end{array}$ & $\begin{array}{l}\text { It is good to put, if you have them, acquired certificates, awards and } \\
\text { distinctions, etc. }\end{array}$ \\
\hline $\begin{array}{l}\text { The customer fears about the } \\
\text { lack of after-sales service }\end{array}$ & $\begin{array}{l}\text { In order to reduce or eliminate the concerns of customers regarding } \\
\text { the lack of after-sales service it is worth informing the client about, } \\
\text { among others, their rights, give a guarantee for the purchased } \\
\text { product or service, communicate the policies on the product. }\end{array}$ \\
\hline
\end{tabular}



as information about the possibility of a personal collection of the purchased goods, placing maps of access, or giving the full address of the seller.

Source: own study based on Dutko 2013, pp. 42-47

The Internet poses new challenges for businesses bringing a lot of opportunities, but also may constitute a serious threat to businesses operating on the Internet. As noted by Kaznowski many web strategy defeats have their origin in the perception of the Internet solely through the prism of its advantages and possibilities (Kaznowski 2008, p. 11). Undoubtedly, e-commerce has many advantages but is also subject to restrictions. Table 1 shows the most common barriers and methods to overcome them.

Table 2. The use of the Internet, its frequency of use and making online purchases in the European Union in 2015 [in \%]

\begin{tabular}{|c|c|c|c|c|c|c|}
\hline \multirow{2}{*}{ 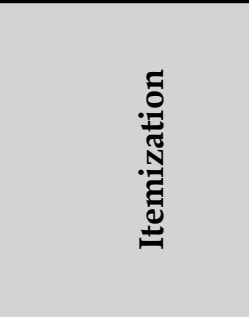 } & \multicolumn{2}{|c|}{$\begin{array}{l}\text { Internet users in } \\
\text { the last: }\end{array}$} & \multirow{2}{*}{ 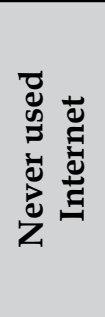 } & \multicolumn{2}{|c|}{$\begin{array}{l}\text { The frequency of the } \\
\text { use of the Internet }\end{array}$} & \multirow{2}{*}{$\begin{array}{l}\text { Proportion of } \\
\text { individuals } \\
\text { who purchased } \\
\text { online within } \\
\text { the last } 12 \\
\text { month }\end{array}$} \\
\hline & 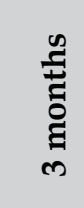 & 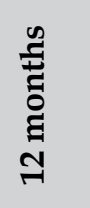 & & 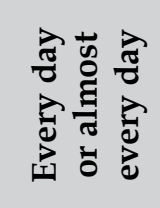 & 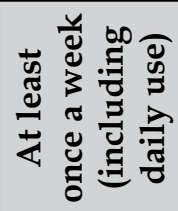 & \\
\hline EU-28 & 79 & 81 & 16 & 67 & 76 & 53 \\
\hline Austria & 84 & 85 & 13 & 68 & 81 & 58 \\
\hline Belgium & 85 & 86 & 13 & 73 & 83 & 55 \\
\hline Bulgaria & 57 & 60 & 35 & 46 & 55 & 18 \\
\hline Cyprus & 72 & 72 & 26 & 63 & 70 & 23 \\
\hline Czech Republic & 81 & 83 & 13 & 63 & 77 & 45 \\
\hline Denmark & 96 & 97 & 3 & 87 & 93 & 79 \\
\hline Estonia & 88 & 89 & 9 & 77 & 86 & 59 \\
\hline Finland & 93 & 93 & 5 & 85 & 91 & 71 \\
\hline France & 85 & 87 & 11 & 68 & 81 & 65 \\
\hline Greece & 67 & 68 & 30 & 55 & 63 & 32 \\
\hline Spain & 79 & 80 & 19 & 64 & 75 & 42 \\
\hline
\end{tabular}




\begin{tabular}{|c|c|c|c|c|c|c|}
\hline Netherlands & 93 & 94 & 4 & 85 & 91 & 71 \\
\hline Croatia & 70 & 71 & 26 & 60 & 66 & 31 \\
\hline Ireland & 80 & 82 & 16 & 67 & 78 & 51 \\
\hline Lithuania & 71 & 72 & 25 & 56 & 69 & 32 \\
\hline Luxembourg & 97 & 98 & 2 & 92 & 97 & 78 \\
\hline Latvia & 79 & 80 & 18 & 66 & 75 & 38 \\
\hline Malta & 76 & 77 & 22 & 69 & 74 & 51 \\
\hline Germany & 88 & 89 & 10 & 75 & 84 & 73 \\
\hline Poland & 68 & 70 & 27 & 52 & 65 & 37 \\
\hline Portugal & 69 & 70 & 28 & 55 & 65 & 31 \\
\hline Romania & 56 & 62 & 32 & 37 & 52 & 11 \\
\hline Slovakia & 78 & 81 & 16 & 60 & 74 & 50 \\
\hline Slovenia & 73 & 75 & 22 & 61 & 71 & 39 \\
\hline Sweden & 91 & 92 & 5 & 82 & 89 & 71 \\
\hline Hungary & 73 & 76 & 21 & 63 & 72 & 36 \\
\hline Great Britain & 92 & 93 & 6 & 83 & 90 & 81 \\
\hline Italy & 66 & 68 & 28 & 62 & 63 & 26 \\
\hline
\end{tabular}

Source: http://ec.europa.eu/eurostat/statistics-explained/images/5/51/Internet_use\%2C_ frequency_of_use_and_online_purchases\%2C_2015_\%28\%25_of_individuals\%29.png [15.01.2016 - date of access]

In the case of online shopping, it seems that the biggest barriers are the lack of direct contact between the customer and the enterprise and the inability to see, touch or test the product before buying it. The buyer must trust the seller that description of the product is included, the posted photos are real, and if you make a purchase of the product it will be sent by the seller. On the other hand, you can identify four main reasons for the growing popularity of online shopping, ie. convenience, more choice, lower prices, the ability to compare prices (Hansen 2005, p. 20; cit.for: Gustavsson, Johansson 2006).

It is worth noting that in 1994 for the first time a purchase was made over the Internet (Szopinski 2012, p. 33), but only the beginning of the twentyfirst century belongs to its intensive development. Depending on the type of activity of the company, it is possible to use the Internet to drive sales directly to customers, other companies or enabling access to specialized information 
resources of this company (Norris, West 2001, p. 9). Table 2 shows the use of the Internet, its frequency of use and making online purchases in the European Union in 2015.

Table 3. The development model for online customer

\begin{tabular}{|c|c|c|}
\hline $\begin{array}{l}\text { Customer } \\
\text { groups }\end{array}$ & Customer characteristics & $\begin{array}{l}\text { Objective of } \\
\text { the enterprise }\end{array}$ \\
\hline $\begin{array}{l}\text { The online } \\
\text { surfer }\end{array}$ & $\begin{array}{l}\text { The online surfer keeps the principle of "I'll just have a look". } \\
\text { Gets acquainted only with the information on the company and } \\
\text { the offered goods and services. Often moves on the Internet } \\
\text { aimlessly going from one website to another and is passive in } \\
\text { relation to the offer. }\end{array}$ & $\begin{array}{l}\text { To increase } \\
\text { reputation }\end{array}$ \\
\hline $\begin{array}{l}\text { The online } \\
\text { consumer }\end{array}$ & $\begin{array}{l}\text { Adds a web address of the company to the favorites menu or } \\
\text { bookmarks, and returns to it to obtain detailed information, or } \\
\text { returns to some services. He/she is interested in the price and } \\
\text { terms of delivery. }\end{array}$ & $\begin{array}{l}\text { To make an } \\
\text { effort to meet } \\
\text { consumer } \\
\text { expectations }\end{array}$ \\
\hline $\begin{array}{l}\text { The online } \\
\text { prosumer }\end{array}$ & $\begin{array}{l}\text { Prosumer is a customer who wants to buy not only standard } \\
\text { products but also products and services tailored to their specific } \\
\text { criteria. Indirectly, it is the manufacturer, who contributes to the } \\
\text { creation of value chain of e-business. Actively and personally } \\
\text { involved, expressing his/her opinion and participating in the } \\
\text { creation of the offer and exchanging their opinion with other } \\
\text { clients. }\end{array}$ & $\begin{array}{l}\text { To promote } \\
\text { interactivity }\end{array}$ \\
\hline $\begin{array}{l}\text { The online } \\
\text { buyer }\end{array}$ & $\begin{array}{l}\text { Requires more and more detailed information on the scope of } \\
\text { the offered goods and services to make a purchase decision. } \\
\text { Makes purchase only then when an offer is satisfactory enough } \\
\text { for him/her. }\end{array}$ & $\begin{array}{l}\text { To strengthen } \\
\text { confidence }\end{array}$ \\
\hline $\begin{array}{l}\text { The key online } \\
\text { customer }\end{array}$ & $\begin{array}{l}\text { They repeat their purchases in the given e-company. Because } \\
\text { of their experience gained from previous purchases the time } \\
\text { needed to take the purchase decision is reduced. }\end{array}$ & $\begin{array}{l}\text { Creating an } \\
\text { individual } \\
\text { supplemental } \\
\text { offer }\end{array}$ \\
\hline
\end{tabular}

Source: own study based on Meier, Stormer 2009, pp. 73-77

According to data from Eurostat, in the last 12 months of 2015 81\% Eurpean Union citizens used the Internet, and 53\% of them made a purchase at online stores. It is also worth noting that the largest group of people who shop on the Internet comes from the United Kingdom (81\%). In second place were the 
residents of Denmark (79\%), and in the next residents of Luxembourg (78\%). Polish residents ranked only at nineteenth place (percentage indicated 37\%), and the following places were residents of Hungary (36\%), Greece and Lithuania (respectively 32\% respondents), Croatia and Portugal (31\%), Italy $26 \%$, Cyprus $(23 \%)$, Bulgaria $(18 \%)$. The last place in terms of the percentage of people using the Internet was taken by Romania (11\%).

To succeed on the e-commerce company should make identification of their customers and take appropriate action to bring customers to buy goods and services. Development model of e-customer proposed by A. Meier and H. Stormer (2009, p.73) distinguishes five groups of clients: online surfer, online consumer, online prosumer, online buyer, key online customers. Each of these groups of customers requires execution of a different order by e-business (table 3).

It is worth mentioning here that the sales strategies on the Internet should focus on two aspects: the first is to convince the client to even make the purchase through new technology (the Internet), and secondly the relationship with the customer should be deepened in order to gain their trust and loyalty (Barska 2014, p. 369).

\section{Materials and methods of research}

Empirical research using the method of questionnaires was conducted from March to July 2014. Among the 349 people participating in the study 72, ie. almost $21 \%$ of respondents do not shop on-line, including 26 women and 46 men. Therefore, for the full analysis 277 questionnaires were taken into account. The sample for the study was selected at random.

The study attempts to answer the following research problems:

- whether education has an impact on the propensity to make purchases over the Internet and the level of concern about Internet security,

- what are the greatest limitations of e-commerce, in the opinion of respondents,

- whether there is a clear link between the assessment of the overall impression of shopping online and satisfaction with the service by the respondents,

- how the consumer behaves on the Internet.

The structure of the study group is as follows: of 277 respondents $60 \%$ were women and $40 \%$ were men. The largest number is in the age ranges of 19-34 years $(44 \%)$ and $35-44$ (nearly $40 \%$ ). Over $10 \%$ were respondents who were between 45 55 years old, and about $5 \%$ were in the range below 19 years of age. The smallest proportion was is in the range of over 55 years of age (over 1\%). The structure of respondents in terms of education is shown in table 4. 
Table 4. The structure of the respondents in terms of education (number of people/percentage)

\begin{tabular}{l|c|c|c|c|c|c}
\hline \multirow{2}{*}{ Itemization } & Total & \multicolumn{5}{|c}{ Education } \\
\cline { 3 - 7 } & & Vocational & Secondary & $\begin{array}{c}\text { Higher } \\
\text { education } \\
\text { education }\end{array}$ & $\begin{array}{c}\text { Higher } \\
\text { education } \\
\text { (master) }\end{array}$ & $\begin{array}{c}\text { Altogether } \\
\text { higher } \\
\text { education }\end{array}$ \\
\hline Women & 165 & 6 & 77 & 47 & 35 & 82 \\
\hline Men & 112 & 28 & 30 & 31 & 23 & 54 \\
\hline Total & 277 & 34 & 107 & 78 & 58 & 136 \\
\hline Share[\%] & 100,00 & 12,3 & 38,6 & 28,2 & 20,9 & 49,1 \\
\hline
\end{tabular}

Source: own study based on the conducted research

As was already mentioned the survey involved 277 respondents. The highest percentage of people declared higher education (bachelor/master), i.e. more than $49 \%$. On the other hand, about 39\% respondents were people with secondary education. The smallest with vocational education (over 12\%).

\section{Analysis of customer behavior on the e-commerce market}

To check whether a person's education influences making purchases over the Internet and reducing concerns about safety on the Internet respondents were asked to specify the frequency of purchasing products through the Internet (table $5)$, and to answer the question about security concerns when making purchases over the Internet (table 6).

Table 5. The frequency of purchasing products through the Internet in terms of education respondents

\begin{tabular}{l|c|c|c|c|c|c|c|c}
\hline \multirow{2}{*}{ Itemization } & \multicolumn{2}{|c|}{ Total } & \multicolumn{5}{c}{ Education } \\
\cline { 3 - 8 } & \multicolumn{2}{|c|}{} & \multicolumn{2}{|c|}{$\begin{array}{c}\text { Vocational educa- } \\
\text { tion }\end{array}$} & $\begin{array}{c}\text { Secondary educa- } \\
\text { tion }\end{array}$ & $\begin{array}{c}\text { Higher education } \\
\text { (bachelor/master) }\end{array}$ \\
\cline { 2 - 8 } & Number & $\begin{array}{c}\text { Percent- } \\
\text { age }\end{array}$ & Number & $\begin{array}{c}\text { Percent- } \\
\text { age }\end{array}$ & Number & $\begin{array}{c}\text { Percent- } \\
\text { age }\end{array}$ & Number & $\begin{array}{c}\text { Percent- } \\
\text { age }\end{array}$ \\
\hline Once a week & 9 & 3,2 & 0 & 0 & 5 & 1,8 & 4 & 1,4 \\
\hline
\end{tabular}




\begin{tabular}{|c|c|c|c|c|c|c|c|c|}
\hline Once a month & 47 & 16,9 & 0 & 0 & 11 & 4,0 & 36 & 13,0 \\
\hline $\begin{array}{l}\text { Several times } \\
\text { a month }\end{array}$ & 13 & 4,8 & 1 & 0,4 & 6 & 2,2 & 6 & 2,2 \\
\hline Once a year & 66 & 23,8 & 9 & 3,2 & 32 & 11,6 & 25 & 9,0 \\
\hline $\begin{array}{l}\text { Several times } \\
\text { a year }\end{array}$ & 118 & 42,6 & 6 & 2,2 & 49 & 17,7 & 63 & 22,7 \\
\hline $\begin{array}{l}\text { Less than once } \\
\text { a year }\end{array}$ & 24 & 8,7 & 18 & 6,5 & 4 & 1,4 & 2 & 0,7 \\
\hline Total & 277 & 100 & 34 & 12,3 & 107 & 38,7 & 136 & 49,0 \\
\hline
\end{tabular}

Source: own study based on the conducted research

Table 6. Fears of respondents of the possibility to experience online fraud when shopping

\begin{tabular}{l|c|c|c|c|c|c|c|c}
\hline \multirow{2}{*}{$\begin{array}{l}\text { Itemiza- } \\
\text { tion }\end{array}$} & \multicolumn{2}{|c|}{ Total } & \multicolumn{2}{c|}{$\begin{array}{c}\text { Vocational educa- } \\
\text { tion }\end{array}$} & \multicolumn{2}{c|}{$\begin{array}{c}\text { Secondary educa- } \\
\text { tion }\end{array}$} & \multicolumn{2}{|c}{$\begin{array}{c}\text { Higher education } \\
\text { (bachelor/master) }\end{array}$} \\
\cline { 2 - 9 } & Number & $\begin{array}{c}\text { Percent- } \\
\text { age }\end{array}$ & Number & $\begin{array}{c}\text { Percent- } \\
\text { age }\end{array}$ & Number & $\begin{array}{c}\text { Percent- } \\
\text { age }\end{array}$ & Number & $\begin{array}{c}\text { Percent- } \\
\text { age }\end{array}$ \\
\hline Yes & 99 & 35,8 & 21 & 7,6 & 43 & 15,6 & 35 & 12,6 \\
\hline No & 178 & 64,2 & 13 & 4,7 & 64 & 23,1 & 101 & 36,4 \\
\hline Total & 277 & 100,0 & 34 & 12,3 & 107 & 38,7 & 136 & 49,0 \\
\hline
\end{tabular}

Source: own study based on the conducted research

As is clear from the conducted research education does influence making purchases over the Internet. Educated people more often buy over the Internet and have fewer security concerns when buying online. Respondents were also asked about the assessment of their financial situation, as it to a significant extent affects the level of expenditure on the purchase of products and their share in the structure of consumption. Given the subjective evaluation of the financial situation of the 277 respondents it can be seen that the majority of respondents, ie. $63 \%$ declared that their situation is good. $19 \%$ rated it as average. In contrast, $9 \%$ of respondents indicated that their financial situation is very good. On the 
other hand, $8 \%$ of those questioned rated it as poor, while $1 \%$ of the respondents marked the answer „,very bad". The analysis of the empirical material also shows that purchases through the Internet are frequently made by people who assess their situation as good or very good. In the group of people declaring to make purchases at least once a year, there were people who found their situation as bad and very bad.

It should also be noted that the respondents as one of the reasons for making online purchases at least once a year pointed to the high cost of delivery of products. Table 7 shows the greatest limitation of e- commerce in the opinion of the respondents.

Table 7. The biggest limitations of e-commerce according to respondents

\begin{tabular}{l|c|c}
\hline Itemization & $\begin{array}{c}\text { Number of } \\
\text { indications }\end{array}$ & $\begin{array}{c}\text { Percentage of } \\
\text { indications }\end{array}$ \\
\hline $\begin{array}{l}\text { Lack of physical contact with the product/inability to } \\
\text { test the product }\end{array}$ & 86 & 31,0 \\
\hline Lack of direct contact with the seller & 35,0 \\
\hline Too little information published about the seller & 0 & 12,6 \\
\hline Lack of information about the status of the company & 0 & 0 \\
\hline Lack of information about the company's achievements & 96 & 34,7 \\
\hline Fear of the lack of after-sales service & 44 & 15,9 \\
\hline Customer distrust of purchases through the Internet & 5 & 1,8 \\
\hline Other, what & 277 & 100,0 \\
\hline Total & & 0 \\
\hline
\end{tabular}

Source: own study based on the conducted research

The main, the most commonly indicated, restrictions identified in the research proceedings of e-commerce are, in the opinion of respondents: fear of the lack of after-sales service and lack of physical contact with the product/inability to test the product. It should also be noted that one in six respondents indicated as the most important barrier to e-commerce customer distrust for purchases through the Internet, and every eighth on too little information published about the seller. But for every twenty-fifth respondent the main limitation was the

Consumer behaviour on the e-commerce market in the light of empirical research in Lubuskie voivodeship 
lack of direct contact with the seller. $2 \%$ of people mentioned other restrictions than those indicated in the questionnaire responses. Among these responses, two individuals showed a too long time to wait for the product, while two more high transportation costs, and one person pointed to the extended processing time for claims and the consequent difficulties associated with return of the product. Seeking relationship between the assessment of the overall impression of shopping online and satisfaction with the service correlations between these characteristics have been scheduled (table 8).

Table 8. The relationship between the assessment of the overall impression of making purchases in an online store and the satisfaction with the service

\begin{tabular}{|c|c|c|c|c|c|c|}
\hline \multirow[b]{2}{*}{$\begin{array}{l}\text { Assessment of the overall } \\
\text { impression of making } \\
\text { purchases in an online } \\
\text { store }\end{array}$} & \multicolumn{5}{|c|}{ Assessment of the satisfaction with the service } & \multirow[b]{2}{*}{ 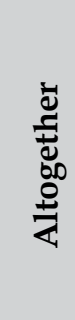 } \\
\hline & 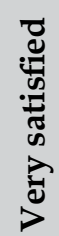 & : & 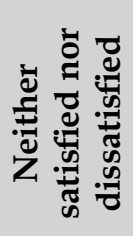 & 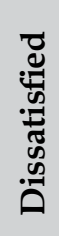 & 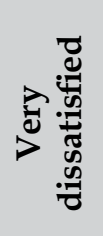 & \\
\hline Very satisfied & 41 & 63 & 0 & 0 & 0 & 104 \\
\hline Satisfied & 7 & 35 & 21 & 41 & 5 & 109 \\
\hline $\begin{array}{l}\text { Neither satisfied nor } \\
\text { dissatisfied }\end{array}$ & 0 & 0 & 19 & 34 & 11 & 64 \\
\hline Dissatisfied & 0 & 0 & 0 & 0 & 0 & 0 \\
\hline Very dissatisfied & 0 & 0 & 0 & 0 & 0 & 0 \\
\hline Altogether & 48 & 98 & 40 & 75 & 16 & 277 \\
\hline
\end{tabular}

Source: own study based on the conducted research

The value of $x^{2}$ statistics evaluating the magnitude of deviations between empirical and theoretical values were determined on the basis of tables 8 and 9 . The calculated chi-square based on table 8 and 9 is: $\chi^{2}=175,4$.

In the chi-squared distribution at the significance level $\alpha=0.05$ and $(r-1)(k-1)=$ 16 degrees of freedom obtained value was 26,296 , and because $c^{2}$ is greater than the critical value, so there is a significant correlation between the measured traits. Whereas the value of the Pearson coefficient is 0,62 , confirming that between 
the studied variables there is a strong correlation. It can therefore be concluded that the assessment of the level of service has an impact on the assessment of the overall experience of shopping in e-shops, and therefore also the level of customer satisfaction with their purchases at online stores.

Table 9. The value of the relationship between the assessment of the overall
impression of purchasing and satisfaction with the service

\begin{tabular}{|c|c|c|c|c|c|c|}
\hline \multirow[b]{2}{*}{$\begin{array}{l}\text { Assessment of the overall } \\
\text { impression of making } \\
\text { purchases in an online store }\end{array}$} & \multicolumn{5}{|c|}{ Assessment of the satisfaction with the service } & \multirow[b]{2}{*}{ 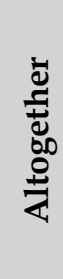 } \\
\hline & $>\frac{\vec{D}}{\stackrel{D}{\mathscr{D}}}$ & 总 & 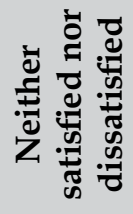 & 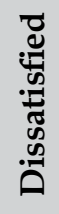 & 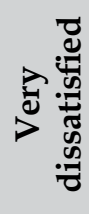 & \\
\hline Very satisfied & 18 & 37 & 15 & 28 & 6 & 104 \\
\hline Satisfied & 19 & 39 & 16 & 29 & 6 & 109 \\
\hline $\begin{array}{l}\text { Neither satisfied nor } \\
\text { dissatisfied }\end{array}$ & 11 & 23 & 9 & 17 & 4 & 64 \\
\hline Dissatisfied & 0 & 0 & 0 & 0 & 0 & 0 \\
\hline Very dissatisfied & 0 & 0 & 0 & 0 & 0 & 0 \\
\hline Altogether & 48 & 99 & 40 & 74 & 16 & 277 \\
\hline
\end{tabular}

Source: own study based on the conducted research

The next question asked the respondents which of the following customer characteristics best describes them according to the model of e-customer proposed by A. Meier and H. Stormer (table 10).

As is clear from the study the largest group of respondents (over 42\%) make purchases in online stores after carefully reading the information relating to e-business and the products it offers, often adding a Web address to favorites returning to it to obtain detailed information, or return to some services. At the same time they show a great interest in the price and terms of delivery. Every fourth respondent pointed to the characteristics of the client online, stating that the decision needs more and more detailed information on the scope of the offered goods and services to make a buying decision. Purchases only then when an offer is satisfactory enough for him/her. In contrast, nearly one in

Consumer behaviour on the e-commerce market in the light of empirical research in Lubuskie voivodeship 
eight respondents indicated that what best describes their process of shopping online is a group of customers known as prosumer online. Noteworthy is the fact that few respondents (over 9\%) identify themselves by the term key online customers. About $12 \%$ of people marked the answer "none of the above/hard to say", thus not called for any group. It should also be noted that none of the persons indicated a group of online surfer, because everyone in the group, ie. 277 respondents purchase goods and services through the Internet.

Table 10. Characteristics of groups of customers in e-commerce

\begin{tabular}{|c|c|c|c|}
\hline $\begin{array}{l}\text { Customer } \\
\text { groups }\end{array}$ & Customer characteristics & $\begin{array}{l}\text { Number of } \\
\text { indications }\end{array}$ & $\begin{array}{l}\text { Percentage } \\
\text { of } \\
\text { indications }\end{array}$ \\
\hline $\begin{array}{l}\text { The online } \\
\text { surfer }\end{array}$ & $\begin{array}{l}\text { Gets acquainted only with the information on the } \\
\text { company and the offered goods and services. Often } \\
\text { moves on the internet aimlessly going from one website } \\
\text { to another and is passive in relation to the offer. }\end{array}$ & 0 & 0 \\
\hline $\begin{array}{l}\text { The online } \\
\text { consumer }\end{array}$ & $\begin{array}{l}\text { Gets acquainted only with the information on the } \\
\text { company and the offered goods and services, often } \\
\text { adds a web address of the company to the favorites } \\
\text { menu or bookmarks, and returns to it to obtain detailed } \\
\text { information, or returns to some services. He/she is } \\
\text { interested in the price and terms of delivery. }\end{array}$ & 117 & 42,2 \\
\hline $\begin{array}{l}\text { The online } \\
\text { prosumer }\end{array}$ & $\begin{array}{l}\text { They buy not only standard products but also products } \\
\text { and services tailored to their individual criteria. They } \\
\text { express their opinion and participate in the creation of } \\
\text { the offer and exchange their opinion with other clients. }\end{array}$ & 35 & 12,6 \\
\hline $\begin{array}{l}\text { The online } \\
\text { buyer }\end{array}$ & $\begin{array}{l}\text { Requires more and more detailed information on } \\
\text { the scope of the offered goods and services to make a } \\
\text { purchase decision. Makes purchase only then when an } \\
\text { offer is satisfactory enough for him/her. }\end{array}$ & 67 & 24,2 \\
\hline $\begin{array}{l}\text { The key } \\
\text { online } \\
\text { customer }\end{array}$ & $\begin{array}{l}\text { They repeat their purchases in the given e-company. } \\
\text { Because of their experience gained from previous } \\
\text { purchases the time needed to take the purchase decision } \\
\text { is reduced. }\end{array}$ & 26 & 9,4 \\
\hline \multicolumn{2}{|c|}{ None of the above/hard to say } & 32 & 11,6 \\
\hline Total & & 277 & 100,0 \\
\hline
\end{tabular}

Source: own study based on Meier, Stormer 2009, pp. 73-77 


\section{Conclussions}

The observation of consumer behavior, their conduct when making online purchases reveals factors that in varying degrees affect their purchasing decisions. They are also an indication for the companies that are facing the dilemma of choosing the means of activating the sale, which will be effective and efficient, and therefore will achieve the strategic goals by the preferred configuration of relations effort/effect (Dybka 2011, p. 174). The key to success is to build trust among email e-clients and gain their loyalty, which will translate into benefits to the enterprise in the form of measurable results.

Analyzing the results of the research it can be stated that as the income increases the tendency to make decisions about purchases through the Internet also increases. In the nearest future it will be a factor in increasing the volume of sales on the e-commerce market in Poland as well as the growing level of education and accessibility to the Internet. In addition, educated people order goods much more often and have fewer security concerns on the Internet.

The analysis of data indicates that the assessment of the level of service has an impact on the assessment of the overall experience of shopping in e-shops, and therefore also the level of customer satisfaction with their purchases in online stores. While the most common constraints identified in the research proceedings of e-commerce are in the opinion of the respondents: fear of the lack of after-sales service and lack of physical contact with the product/ inability to test the product. This requires a change in the approach of sellers to customers from the considered market and greater care to provide correct and complete information about the product. From the analysis of the empirical material it ensues that according to A. Meier and H. Stromer's model of e-customer development the largest group of respondents constitute online consumers (over $42 \%$ ), whereas the smallest the key online customers (over 9\%). Online customers account for more than $24 \%$ and online prosumers for more than $12 \%$. It is worth noting that each of these groups has a specific pattern - the type of conduct that should be associated with the adoption by an e-enterprise of specific actions regarding the particular group of e-customers. Undoubtedly, recognition by the company of the main groups of customers and then providing them with the expected values can lead to achieving a goal by e-business in the form that their offer is selected and not a competitive one.

Consumer behaviour on the e-commerce market in the light of empirical research in Lubuskie voivodeship 


\section{Summary}

Consumer behaviour on the e-commerce market in the light of empirical research in Lubuskie voivodeship

The main aim of this article was to identify the behavior of consumers in the e-commerce market in Poland, according to the model of e-customer as adopted by Meier and Stormer. An attempt was made to answer the following questions: whether education has an impact on the propensity to make purchases over the Internet and the level of concern about Internet security, what are the greatest limitations of e-commerce, whether there is a clear link between the assessment of the overall impression of shopping online and satisfaction with service. The study shows that the largest group of respondents make purchases in online stores after carefully reading the information relating to the e-business and the products it offers, often adding a Web address to favorites returning later to obtain detailed information, or return to some services. At the same time they show a great interest in the price and terms of delivery. The research procedure used the analysis of literature, statistical data and results of the survey respondents of Lubuskie voivodship.

Key words: consumer behavior, the model of e-customer e-commerce, customer, Lubuskie voivodship.

\section{Streszczenie}

Zachowania konsumenta na rynku e-commerce w świetle wyników badań empirycznych w województwie lubuskim

Głównym celem artykułu było zidentyfikowanie zachowań konsumentów na rynku handlu elektronicznego w Polsce, zgodnie $z$ modelem rozwoju e-klienta przyjętym przez A. Meiera i H. Stormera. Podjęto również próbę odpowiedzi na następujące pytania: czy wykształcenie ma wpływ na skłonność dokonywania zakupów przez Internet i poziom obaw związanych $\mathrm{z}$ bezpieczeństwem $\mathrm{w}$ sieci, jakie są największe ograniczenia handlu elektronicznego, czy istnieje wyraźny związek między oceną ogólnego wrażenia $\mathrm{z}$ dokonywania zakupów w sklepach online a zadowoleniem $\mathrm{z}$ obsługi. $\mathrm{Z}$ przeprowadzonych badań wynika, że największa grupa respondentów dokonuje 
zakupów w sklepach online po dokładnym zapoznaniu się z informacjami dotyczącymi przedsiębiorstwa i oferowanych przez niego produktów, często dodając adres strony do ulubionych powracają do niej, aby uzyskać dokładniejsze informacje lub też powracają do niektórych usług. Jednocześnie wykazują duże zainteresowanie ceną i warunkami dostaw. W postępowaniu badawczym wykorzystano analize literatury, danych statystycznych oraz wyniki przeprowadzonego badania ankietowego wśród respondentów województwa lubuskiego.

\section{Słowa}

kluczowe: zachowania konsumenta, model rozwoju e-klienta, e-commerce, klient, województwo lubuskie.

\section{References}

1. A wave of Digital change: Trends in Digital. E- innowation 2013 (2013), Deloitte Poland, http://www2.deloitte.com/content/dam/Deloitte/ global/Documents/About-Deloitte/pl_Digital_Trends_2013_Final2.pdf (15.01.2016 - access date).

2. Barska A. (2014), Zaufanie konsumentów generacji $Y$ wobec handlu elektronicznego, [in:] U. Kłosiewicz-Górecka (ed.), Handel wewnętrzny $w$ Polsce 2009-2014. Zmiany w handlu hurtowym i detalicznym. Technologie informacyjne $i$ komunikacyjne $w$ handlu. Handel Internetowy, IBRKK, Warszawa.

3. Cimochowski G., Hutten-Czapski F., Rał M., Sass W. (2011), Polska Internetowa. Jak Internet dokonuje transformacji polskiej gospodarki, http:// www.polskaInternetowa.pl/pdf/raport_BCG_ polska_Internetowa.pdf (15.01.2016 - access date).

4. Dutko M. (2013), E-biznes-poradnik. Poradnik praktyka. Postaw na biznes $w$ sieci, Helion, Gliwice.

5. Dybka S. (2011), Uwarunkowania decyzji zakupowych klientów dyskontowych, [in:] J. Witek (ed.), Studia i materiaty Polskiego Stowarzyszenia Zarządzania Wiedza, Polskie Stowarzyszenie Zarządzania Wiedzą, Bydgoszcz.

6. Garapich A. (2012), E-commerce w Polsce: Rynek. Nabywcy. Trendy, PBI, http://www.slideshare.net/P_B_I/e-commerce-w-polsce (15.01.2016 access date).

7. Gregor B., Stawiszyński M. (2002), E-commerce, Oficyna Wydawnicza Branta, Bydgoszcz-Łódź.

8. Handel Internetowy w Polsce 2015. Analiza i prognoza rynku e-commerce na lata 2015-2020, https://www.pmrpublications.com/product/HandelInternetowy-w-Polsce-2015 (15.01.2016 - access date).

Consumer behaviour on the e-commerce market in the light of empirical research in Lubuskie voivodeship 
9. Hansen J. (2005), 100 sidor Om att starta, driva och marknadsföra en butik på nätet, Redaktionen, Stockholm.

10. Gustavsson M., Johansson A. M. (2006), Consumer trust in e-commerce, The Department of Business Studies, Kristianstad.

11. http://ec.europa.eu/eurostat/statistics-explained/images/5/51/ Internet_use\%2C_frequency _of_use_and_online_purchases\%2C_2015_ $\% 28 \% 25$ _of_individuals\%29.png (15.01.2016 - access date).

12. Kaznowski D. (2008), Nowy marketing, VFP Communications, Warszawa.

13. Meier A., Stormer H. (2009), Business and Commerce. Managing the Digital Value Chain, Springer, Berlin.

14. Michałowska M., Kotylak S., Danielak W. (2015), Forming relationships on the e-commerce market as a basis to build loyalty and create value for the customer. Empirical findings, "Management", Vol. 19, No. 1.

15. Norris M., WestS. (2001), E-biznes, Wydawnictwa Komunikacji i Łączności, Warszawa.

16. Szopiński T. (2012), E-konsument na rynku ustug, CedeWu, Warszawa. 